\begin{tabular}{|c|c|c|}
\hline$\exists$ & $\begin{array}{c}\text { International Journal of Current Research } \\
\text { and Academic Review }\end{array}$ & 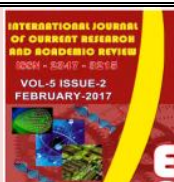 \\
\hline $\begin{array}{l} \\
\text { EXCELLENT } \\
\text { PUBLISHERS }\end{array}$ & $\begin{array}{c}\text { ISSN: } 2347-3215 \text { (Online), } ; \text { Volume 5;,;Number } 2 \text { (Feb } \\
\text { Journal hompage: http://www.ijcrar.com }\end{array}$ & \\
\hline
\end{tabular}

doi: http://dx.doi.org/10.20546/ijcrar.2017.502.005

\title{
Cultivation of Oyster Mushroom and Recovery of Value Added by-products from Biodegradable Lignocellulosic Waste Materials by Solid State Fermentation
}

\author{
Rashmi Padhye $^{1 *}$ and Sneha Atawane ${ }^{2}$ \\ ${ }^{1}$ Department of Biochemistry, Hislop College, Temple Road, Nagpur, 440001, India \\ ${ }^{2}$ Department of Biotechnology, Pillai's College, Panvel, Navi Mumbai, India \\ *Corresponding author
}

\begin{abstract}
In the present study, the edible fungus Pleurotus sajor-caju was investigated for its ability to grow on different lignocellulosic substrates namely, water hyacinth, wood chips and paddy and to produce various lignocellulolytic enzymes such as cellulase, xylanase and pectinase. The production pattern of the extracellular enzymes, total proteins and reducing sugar level was studied during the growth of this fungus under Solid State Fermentation (SSF) for a period of 56 days. Wheat grains were rapidly utilized and consumed by the fungus as a simple carbon source and were used for spawn formation. Different lignocellulosic complex carbon sources served as substrates and exhibited better induction process for more enzyme biosynthesis and production. The maximum activity of enzymes was obtained on $28^{\text {th }}$ and $56^{\text {th }}$ day of culture growth. The total yield of mushroom grown on different lignocellulosic substrates and levels of cellulose, pectinase and xylanase was also detected.
\end{abstract}

\section{Article Info}

Accepted: 25 January 2017

Available Online: 20 February 2017

\section{Keywords}

P. sajor-caju, Cellulase, Pectinase, Xylanase, Oyster mushrooms, Solid state fermentation.

\section{Introduction}

Large amount of lignocellulosic wastes are generated through forestry and agricultural practices, paper-pulp industries, timber industries and many agro industries. Currently, much of these lignocellulosic wastes are disposed by biomass burning or shredded and composted which results in environmental pollution. Fungal bioconversion of wood is an important agent responsible for the environmental carbon circulation (Kirk and Farrell 1987, Eriksson et al., 1990) and moreover by making use of appropriate bioconversion technology, these wastes can be converted into variety of value added products. Various lignocellulosic substrates and whiterot fungi have been used successfully in submerged and solid-state fermentation for lignocellulolytic enzyme production. The type and composition of lignocellulosic substrate appear to determine the type and amount of enzyme produced by basidiomycetes (Elisashvili et al., 2006). Compared with submerged fermentation, solidstate fermentation provides certain advantages of fungal enzyme production with the aspect of application in bioprocesses such as biobleaching, biopulping, bioremediation etc (Stajic et al., 2006).

It has also been shown that, during solid-state fermentation of lignocellulosic materials, some fungi produce a different set of enzymes compared with synthetic liquid culture. Many of the mushroom species have the potential to produce and secrete a wide 
spectrum of enzymes, like cellulases, hemicellulases, xylanases, lignin peroxidase, manganese peroxidase and laccases which enable them to thrive over a range of lignocellulosic wastes and produce protein rich biomass of fruiting bodies. During cultivation on lignocellulosic substrates enzyme activities change when shift between substrate colonization and fructification stages of mushroom growth (Omoanghe and Mikiashvili, 2009).

Mushrooms are very nutritious products which are in rich in crude fiber and protein. Mushrooms also contain low fat, low calories and good vitamins. In addition, many mushrooms possess multi-functional medicinal properties. (Heleno et al., 2010; Mattila et al., 2001). In the present study, three biodegradable lignocellulosic waste materials namely, Water hyacinth (Eichhornia crassipes) a fast growing perennial aquatic weed widely distributed throughout the world. Wood chips and paddy were used as substrate for oyster mushroom cultivation using Pleurotus sajor-caju and recovery of value added byproducts such as various enzymes, mushrooms and reducing sugar was studied and compared.

\section{Materials and Methods}

\section{Culture}

Culture of Pleurotus sajor-caju was obtained from the Department of Biotechnology, Pillai's college New Panvel.

\section{Substrates}

Fresh and healthy Water Hyacinth whole plants were collected from a freshwater pond of Palm Beach road, Nerul, wood chips were obtained from carpenter's shop and paddy straw was obtained from APMC market, Vashi, Navi Mumbai.

\section{Mushroom production}

\section{Processing of substrate}

The water hyacinth was thoroughly washed several times with tap water to remove adhering dirt. Samples of stem, petiole and leaf of the fresh water hyacinth selected as the substrate material were chopped into small pieces $(\sim 1-2 \mathrm{~cm})$, blended to small particles $(\sim 3-5 \mathrm{~mm})$, and finally dried in a hot air oven at $80^{\circ} \mathrm{C}$ for $3-4$ hours. Similarly, wood chips and paddy straw were also chopped into small pieces and washed extensively with tap water to remove soil particles and dried in hot air oven at $80^{\circ} \mathrm{C}$ for $3-4$ hours.

\section{Preparation of substrates for inoculation}

Water hyacinth, Wood chips and Paddy straw were soaked for 3 hours in hot tap water containing $5 \% \mathrm{CaCO}_{3}$ for $\mathrm{pH}$ adjustment to 6.5-7.9 which is an optimal $\mathrm{pH}$ for Pleurotus (Iqbal and Shah, 1989). After 3 hours, the excess water was again drained off. All the three substrates were then sterilized by autoclaving at $121^{\circ} \mathrm{C}$ for 1 hour.

\section{Spawn preparation}

Whole wheat grains were washed with tap water to remove dirt and floating seeds. These wheat grains were then soaked in hot tap water overnight for the grains to become soft. Excess water was then removed from the grains. The grains were mixed with $0.5 \% \mathrm{CaCO}_{3}$ on dry weight basis (to adjust $\mathrm{pH}$ ). These treated grains were then filled in bottles and autoclaved for two consecutive days at $121^{\circ} \mathrm{C}$ for 1 hour. These grains were then inoculated with actively growing mycelium of the $P$. sajor-caju from potato dextrose agar slants. These bottles were then incubated at $(27 \pm 2){ }^{\circ} \mathrm{C}$ in dark for mycelial growth for 12 to 15 days.

\section{Substrate inoculation}

The spawn of $P$. sajor-caju was used to inoculate the sterile substrate. $500 \mathrm{gm}$ of each substrate was inoculated with $200 \mathrm{gm}$ of spawn. The plastic bags were sterilized by wiping with alcohol. Spawning was done in layers by alternately layering the substrate with spawn.. The procedure was followed until the plastic bag was full. These bags were then sealed and placed in well ventilated dark room at $25-27^{\circ} \mathrm{C}$ as growth of mycelium does not require light. After three days of incubation, fine holes were made into each spawned bag for proper aeration.

\section{Fruiting}

When the bags were fully invaded with mycelia they were taken out of the dark room and kept exposed to light. The plastic bags were cut open on the sides without disturbing the bed and sprayed with water twice a day using a hand sprayer. The mass of substrate was kept undisturbed for the appearance of fruiting bodies. The spray of water was discontinued a day before the harvest 
of the fruiting bodies. The mushrooms were collected in three flushes.

\section{Preparation of enzyme extract}

For enzyme extraction, $10 \mathrm{gm}$ of each autoclaved substrate was inoculated separately into zip-lock pouch with $4 \mathrm{gm}$ spawn. Seven such pouches of each substrate were prepared. The pouches were also incubated in dark room at $25-27^{\circ} \mathrm{C}$ with maintenance of proper humidity. These pouches were sacrificed after every 14 days interval for extraction of different enzymes.

The colonized substrate from the pouches was transferred into $250 \mathrm{ml}$ Erlenmeyer flasks and $100 \mathrm{ml}$ acetate buffer ( $\mathrm{pH}$ 5.4) was added to these. The flasks were then kept on shaker for 2 hours. After 2 hours the extracts were filtered through muslin cloth. The filtrates were centrifuged at $5000 \mathrm{rpm}$ for 10 minutes. The enzyme extracts were then refrigerated for further analysis of enzymes.

\section{Analyses}

\section{Cellulase assay}

Determination of cellulase activity was based on the colorimetric quantification (at $540 \mathrm{~nm}$ ) of free glucose released by the hydrolysis of cellulose using substrate.

One IU is the amount of enzyme that liberates one $\mu$ mol glucose per minute under test conditions (i.e., pH 5.4, temperature $37^{\circ} \mathrm{C}$ and substrate concentration).

\section{FPase, CMCase, B-glucosidase assay}

Cellulase activity was measured as filter paper activity units. Filter paper activity is a combined assay for endo and exo $\beta-1,4$ glucanase. $1 \mathrm{ml}$ of enzyme extract was incubated with Whatman no. 1 filter paper strip $(1.0 \mathrm{~cm}$ x $6.0 \mathrm{~cm}$ ) and $2 \mathrm{ml}$ of $0.1 \mathrm{M}$ acetate buffer (pH 5.4) for 1 hour at $50^{\circ} \mathrm{C} .1 \mathrm{ml}$ of enzyme extract was incubated for $30 \mathrm{~min}$ at $50^{\circ} \mathrm{C}$ with $1 \mathrm{ml}$ of $1 \% \mathrm{CMC}$ (for CMCase) and $1 \%$ Salicin (for $\beta$-glucosidase) prepared in $0.1 \mathrm{M}$ acetate buffer. Final volume was made up to $3 \mathrm{ml}$ with buffer. The reaction was terminated by adding $3 \mathrm{ml}$ of DNSA reagent and the mixture was boiled for 5 minutes and cooled. The absorbance was read at $540 \mathrm{~nm}$ using colorimeter. Control was run without filter paper strip to apply corrections for the reducing sugars present in sample. This absorbance was translated by plotting against standard curve to get $\mu \mathrm{g}$ of glucose to calculate units of enzyme activity.

\section{Xylanase assay}

$1 \mathrm{ml}$ of enzyme extract was incubated with $1 \mathrm{ml}$ of $0.1 \mathrm{M}$ acetate buffer $(\mathrm{pH} 5.4)$ and $1 \mathrm{ml}$ of $0.5 \%$ (wt/vol) Birchwood xylan prepared in $0.1 \mathrm{M}$ acetate buffer $(\mathrm{pH}$ 5.4). Reaction mixture was incubated at $40^{\circ} \mathrm{C}$ for $30 \mathrm{~min}$. The amount of reducing sugar released was determined by Miller's method using D-xylose as standard. One unit of xylanase is defined as the amount of enzyme which releases one $\mu \mathrm{mol}$ of $\mathrm{D}$-xylose per minute under assay conditions.

\section{Pectinase assay}

$1 \mathrm{ml}$ of enzyme extract was incubated with $1 \mathrm{ml}$ of $0.1 \mathrm{M}$ acetate buffer ( $\mathrm{pH} 5.4)$ and $1 \mathrm{ml}$ of $0.5 \%$ pectin prepared in $0.1 \mathrm{M}$ acetate buffer ( $\mathrm{pH}$ 5.4). Reaction mixture was incubated at $40^{\circ} \mathrm{C}$ for $30 \mathrm{~min}$. The amount of reducing sugar released was determined by Miller's method using D-galacturonic acid as standard. One unit of pectinase is defined as the amount of enzyme which releases one $\mu$ mol of reducing sugars per minute under assay conditions.

\section{Determination of free reducing sugars}

The amount of free reducing sugars in a known volume $(1 \mathrm{ml})$ of enzyme extract was determined by DNS method of Miller (1959).

\section{Protein determination}

Protein content in both the enzyme extract and mushroom was determined colorimetrically using Bradford's method (1976) by measuring optical density at $600 \mathrm{~nm}$. The amount of protein $(\mu \mathrm{g} / \mathrm{ml})$ was calculated using standard curve of Bovine Serum Albumin (BSA).

\section{Determination of lignin content}

Gravimetric determination of lignin in cultivated substrates was estimated according to (Sun et al., 1996 and Adsul et al., (2005). 10 gm of air-dried substrate was fragmented into small pieces and suspended in $200 \mathrm{ml} 1$ $\%$ (wt /vol) aqueous solution of $\mathrm{NaOH}$. The mixture was autoclaved at $121^{\circ} \mathrm{C}$ for $1 \mathrm{hr}$ in $500 \mathrm{ml}$ Erlenmeyer flask. The residues were collected and extremely washed by tap water until neutral $\mathrm{pH}$ and then dried at $80{ }^{\circ} \mathrm{C}$ for 48 
$\mathrm{hr}$ and weighed. The loss of weight is corresponded to lignin content.

\section{Moisture content}

A known amount of mushroom sample was taken in a dry, pre weighed china dish. The china dish with sample was weighed before and after drying at $80^{\circ} \mathrm{C}$ in an oven. Moisture content of substrate sample was calculated using formula:

Moisture content $=\mathrm{A}-\mathrm{B} / \mathrm{A} \times 100$

Where A: wet weight of the sample and B: oven dried weight of the sample.

\section{Determination of organic carbon}

The organic carbon in the three substrates was determined by Walkey and Black method.

\section{Determination of phosphorus content}

The phosphorus content in the substrates was determined by Fiske-Subbarow Acid molybdate method.

\section{Nitrogen estimation}

Nitrogen values can be converted to crude protein using the formula: Crude protein $=(\mathrm{N} \times 6.25)$ (Jones et al., 1942).

Hence, $\mathrm{N}=$ crude protein/ 6.25 .

\section{Results and Discussion}

Cultivation of mushroom presents an economically important biotechnological industry that has developed all over the world. It is estimated that more than 10 million metric ton of edible and medicinal mushrooms were produced in 2004 in various countries (Royse, 2005). Mushroom can convert the huge lignocellulosic wastes into a wide variety of products (edible or medicinal food, feed and fertilizers), protecting and regenerating the environment.

Under present investigation $P$. sajor caju was cultivated on different substrates and incubated at $25-30^{\circ} \mathrm{C}$ along 56 days. Pouches of each substrate were sacrificed after every 14 days of incubation. Enzymes, reducing sugar and protein were estimated in enzyme extract obtained from these sacrificed pouches.
The activity of FPase (exoglucanse) was observed on $0^{\text {th }}$ day of incubation in water hyacinth and paddy whereas it was not detected in case of wood chips. This could be due to the hydrolyzed wheat grains used for spawn preparation of $P$. sajor-caju. Maximum FPase activity was found on $56^{\text {th }}$ day of incubation in wood chips (4 $\mathrm{IU} / \mathrm{ml}$ ) followed by paddy $(2 \mathrm{IU} / \mathrm{ml})$. In case of water hyacinth, maximum activity $(1 \mathrm{IU} / \mathrm{ml})$ was observed on $28^{\text {th }}$ day which further decreased with further incubation. Sherief et al., (2010) observed maximum exoglucanse activity on rice straw and sawdust after 20 days which also showed induction quite late. Thus, maximum FP ase (exoglucanse) activity was reported in wood chips on 56 days of incubation.

$P$. sajor-caju culture grown on water hyacinth and wood chips showed endoglucanase or CM Case activity from $0^{\text {th }}$ day of incubation whereas it was not detected in case of paddy as substrate at this stage. The CM Case activity gradually increased till $28^{\text {th }}$ day in both water hyacinth and wood chips. In case of paddy as substrate, the CM Case was induced at a later stage. The peak values of CM Case activity were found on $56^{\text {th }}$ day and were recorded as $12.66 \mathrm{IU} / \mathrm{ml}$ in case of both substrates wood chips and paddy. Maximum activity on water hyacinth $(12.33 \mathrm{IU} / \mathrm{ml})$ was observed on $28^{\text {th }}$ day which is induced much earlier.

$\beta$-glucosidase activity was observed in water hyacinth and wood chips after 7 days of incubation however the activity was observed in paddy on $0^{\text {th }}$ day. Maximum $\beta$ glucosidase activity was observed on $56^{\text {th }}$ day in both wood chips and paddy and was found to be $4 \mathrm{IU} / \mathrm{ml}$ and $7 \mathrm{IU} / \mathrm{ml}$ respectively. In case of water hyacinth maximum $\beta$-glucosidase activity was observed on $28^{\text {th }}$ day and was recorded as $9.33 \mathrm{IU} / \mathrm{ml}$.

It has been observed that the maximum cellulase activity was induced at an earlier stage in water hyacinth when compared to wood chips and paddy. This could be attributed to the lesser lignin content in water hyacinth as compared to other two substrates (Table 1) (Fig. 1-3).

Xylanase activity in case of water hyacinth was found to increase gradually from 0 to 56 days and maximum xylanase production was observed on $56^{\text {th }}$ day which was recorded as $21.5 \mathrm{IU} / \mathrm{ml}$. Early xylanase production was observed with wood chips as substrate compared with other two lignocellulosic materials used in this study. This result is in agreement with the result obtained by Sherief et al., (2010). This could be due to inductive effect of hemicellulose on xylanase production. 
Hemicellulose in wood chips is more than paddy straw and water hyacinth (Table 1). In case of both wood chips and paddy, there was a drop in xylanase production as observed on $14^{\text {th }}$ day after which the activity increases significantly. Maximum xylanase activity was observed on $56^{\text {th }}$ day in both substrates. The activity was found to be $11.5 \mathrm{IU} / \mathrm{ml}$ and $12.5 \mathrm{IU} / \mathrm{ml}$ on wood chips and paddy respectively (Fig. 4). This is in agreement with the results obtained by Techapun et al., (2003) who reported that paddy straw was not a good inducer of xylanase. Studies carried out by Sherief et al., (2010) showed that optimum xylanase production was recorded after 20 days in case of sawdust and after 45 days in case of rice straw. Earlier studies indicated that optimum xylanase production was detected after 16 days by $P$. ostreatus grown on wheat straw (Garzillo et al., 1994. Qinnghe et al., (2004) indicated that corncob which contains high level of xylan (33\%) has been used as an induction substrate for different xylanases production by $P$. ostreatus.

High level of pectinase activity was observed initially on $0^{\text {th }}$ day of incubation in all the three substrates. This could be attributed to spawn on wheat grains. The pectinase activity gradually fell from 0 to 14 days of incubation. After $14^{\text {th }}$ day, the activity was again found to increase gradually till $56^{\text {th }}$ days (Fig. 5). The rise and fall in the activity could be related to the shift in carbon source used by $P$. sajor-caju. Initially $P$. sajor-caju utilised wheat grains as carbon source. When wheat grains were used up, the organism switched over to the lignocellulosic material (substrate) as carbon source. Maximum pectinase activity was observed on $56^{\text {th }}$ day in all three substrates. The activities were $51.33 \mathrm{IU} / \mathrm{ml}$, $29.03 \mathrm{IU} / \mathrm{ml}$ and $31 \mathrm{IU} / \mathrm{ml}$ on water hyacinth, wood chips and paddy respectively. Much work on pectinase production by Pleurotus species has not been carried out previously. Our aim of studying this enzyme is due to its importance and wide use in food industry during extraction and clarification of fruit juice, tissue maceration and also in paper and pulp industry, waste management, animal feed and textile industry. A.A. Sherief et al., (2010) showed that $P$. ostreatus pectinase was optimally produced after 35 days in case of sawdust and after 20 days in case of rice straw.

Initial high reducing sugar content in the culture filtrate ( 0 day) may be due to the hydrolysis of wheat grains during autoclaving and hydrolysis of grains by $P$. sajorcaju during spawn development. Maximum production of reducing sugar released then gradually decreased thereafter and an increase in the $\beta$-glucosidase activity was seen (Fig. 6). There was a decrease in the concentration of reducing sugar after 28 days when the fruiting bodies start to appear. This could be due to degradative enzymes from mushroom growing on the three substrates including cellulase and xylanase act on the hemicellulosic components converting them into mixture of solubilized sugars, mainly oligomer. The sugars are then available as essential nutrients for growth of mushrooms (Anakalo Kihumbu, 2008). Mushrooms utilize reducing sugar for growth and thus prevent feedback inhibition of degradative enzymes like $\beta$ glucosidase (Ryu and Mandels, 1980). Thus an increase in cellulase activity was seen. In case of water hyacinth and wood chips maximum values of reducing sugar were obtained on $14^{\text {th }}$ day which were $1200 \mu \mathrm{g} / \mathrm{ml}$ and $990 \mu \mathrm{g} / \mathrm{ml}$ respectively. Highest value of reducing sugar in paddy was obtained on $28^{\text {th }}$ day which was recorded as $1260 \mu \mathrm{g} / \mathrm{ml}$.

Protein pattern showed gradual and significant increase in total unspecified protein production by $P$. sajor-caju and correlated positively with fermentation periods. The value of protein reached maximum on $28^{\text {th }}$ day of incubation for water hyacinth $(174 \mu \mathrm{g} / \mathrm{ml})$ and paddy $(188 \mu \mathrm{g} / \mathrm{ml})$ and on $56^{\text {th }}$ day of incubation for wood chips (124 $\mu \mathrm{g} / \mathrm{ml})$ (Fig. 7). Sherief et al., (2010) observed that the value of protein reached maximum after 40 days of incubation for rice straw and after 45 days incubation for sawdust. The observed increase in protein content during mushroom growth and fruiting period indicates a positive substrate bioconversion (Alemawor et al., 2009) (Table 2 ). Most of the extracellular fungal enzymes produced during bioconversion process by the growing fungus are proteinaceous in nature, thus the spent enzymes could contribute some amount of protein to the substratum (Kadari, 1999).

Protein, the most important constituent of food material is found in oyster mushroom. The total protein content in dry powder of mushroom cultivated on different substrates was estimated by Bradford's method (1976). The highest content of protein was found in mushroom grown on water hyacinth which was followed by wood chips and then paddy (Table 3). Chang and Miles (1988) reported that the range of protein in oyster mushroom was $19-35 \%$. Findings of present experiment differed from finding of Chang and Miles (1988) but are in accordance with those obtained by Sarker et al., (2007). Badshah et al., (1994) and Zaman (2004) found that the protein content of mushroom is affected by nutrient status of the substrate. 
Table.1 Composition of different lignocellulosic wastes

\begin{tabular}{|l|l|l|l|}
\hline $\begin{array}{l}\text { Lignocellulosic } \\
\text { waste }\end{array}$ & $\begin{array}{l}\text { Cellulose } \\
(\boldsymbol{\%})\end{array}$ & $\begin{array}{l}\text { Hemicellulose } \\
(\mathbf{\%})\end{array}$ & $\begin{array}{l}\text { Lignin } \\
(\mathbf{\%})\end{array}$ \\
\hline Wood chips & $40-50$ & $20-40$ & $14-19$ \\
\hline Paddy & 29.45 & 24.7 & 16.78 \\
\hline Water hyacinth & 23.0 & 35.0 & 7.5 \\
\hline
\end{tabular}

Table.2 Comparison of bioconversion efficiency of lignocellulosics into value added products

\begin{tabular}{|c|c|c|c|}
\hline \multicolumn{1}{|c|}{ Value Added Products } & Water hyacinth & Wood chips & Paddy \\
\hline 1. Mushroom & & & \\
\hline$\bullet \quad$ Yield & 10.9 & 11 & 14 \\
\hline$\bullet \quad$ Protein & 17.2 & 11.5 & 9.9 \\
\hline 2. Enzymes(IU/ml) & & & \\
\hline$\bullet \quad$ Cellulase & & & \\
\hline FPase & 1 & 4 & 2 \\
\hline CMCase & 9.33 & 12.33 & 12.66 \\
\hline$\beta-G l u c o s i d a s e$ & 51.33 & 29.03 & 7 \\
\hline$\bullet \quad$ Pectinase & 21.5 & 11.5 & 12.5 \\
\hline$\bullet \quad$ Xylanase & 1200 & 990 & 1260 \\
\hline 3. Reducing Sugar $(\boldsymbol{\mu g} / \mathbf{m l})$ & 174 & 124 & 188 \\
\hline 4. Protein $(\boldsymbol{\mu g} / \mathbf{m l})$ & & & \\
\hline
\end{tabular}

Table.3 Effect of different substrates on protein content of oyster mushroom

\begin{tabular}{|c|c|c|}
\hline Substrates & $\begin{array}{c}\text { Protein Content } \\
\text { (Gm \%) }\end{array}$ & Yield (\%) \\
\hline Water hyacinth & 17.2 & 10.9 \\
\hline Wood chips & 11.5 & 11 \\
\hline Paddy & 9.9 & 14 \\
\hline
\end{tabular}

Table.4 Comparison of carbon, nitrogen and phosphorus content of different substrates

\begin{tabular}{|c|c|c|c|c|}
\hline Substrates & Carbon (\%) & Nitrogen (\%) & C:N ratio & Phosphorus \\
\hline Water hyacinth & 15 & 1.32 & 7.30 & 78.5 \\
\hline Wood chips & 22.98 & 0.703 & 32.69 & 6 \\
\hline Paddy & 46.8 & 0.69 & 67.82 & 24 \\
\hline
\end{tabular}


Fig.1 Cellulase activity with water hyacinth

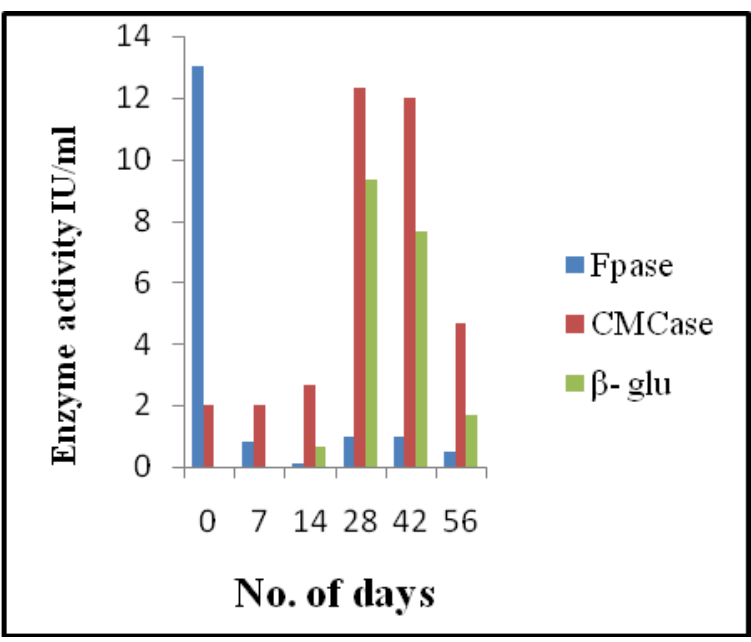

Fig.2 Cellulase activity with wood chips

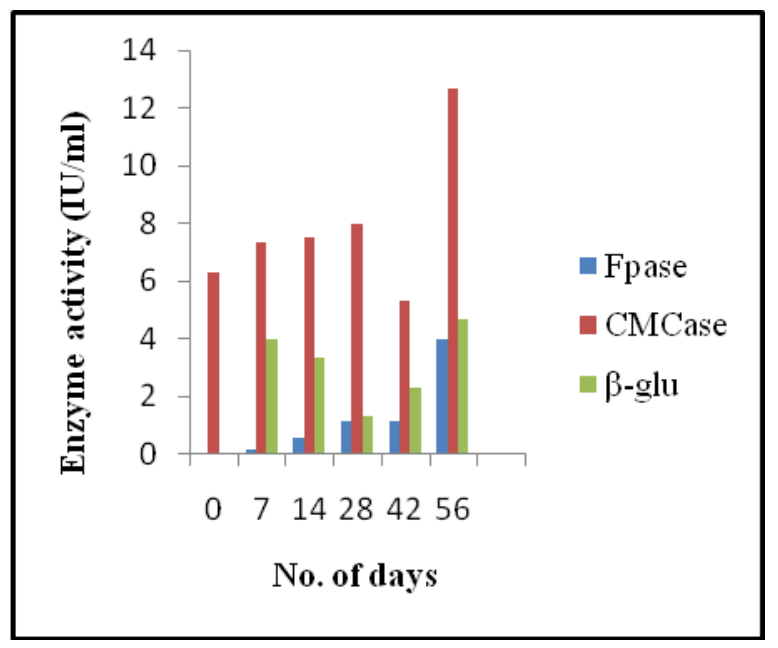

Fig.3 Cellulase activity with paddy

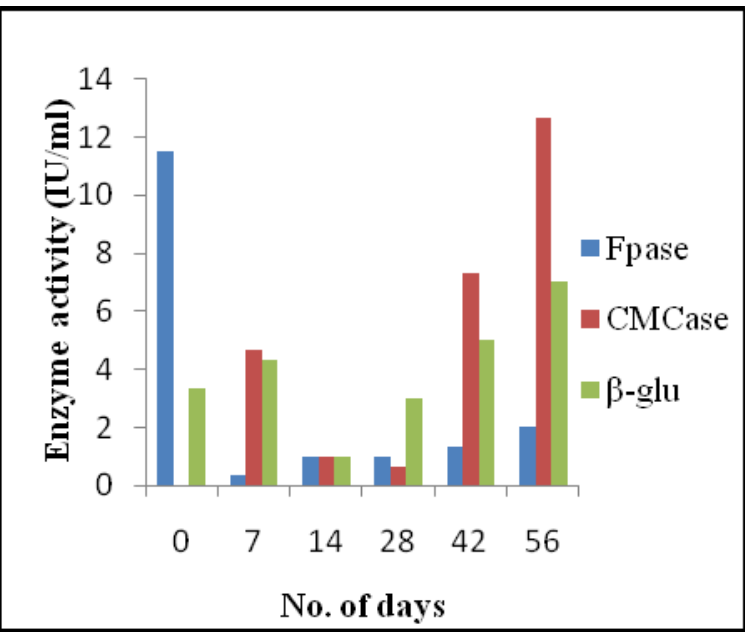


Fig.4 Xylanase activity on different substrates

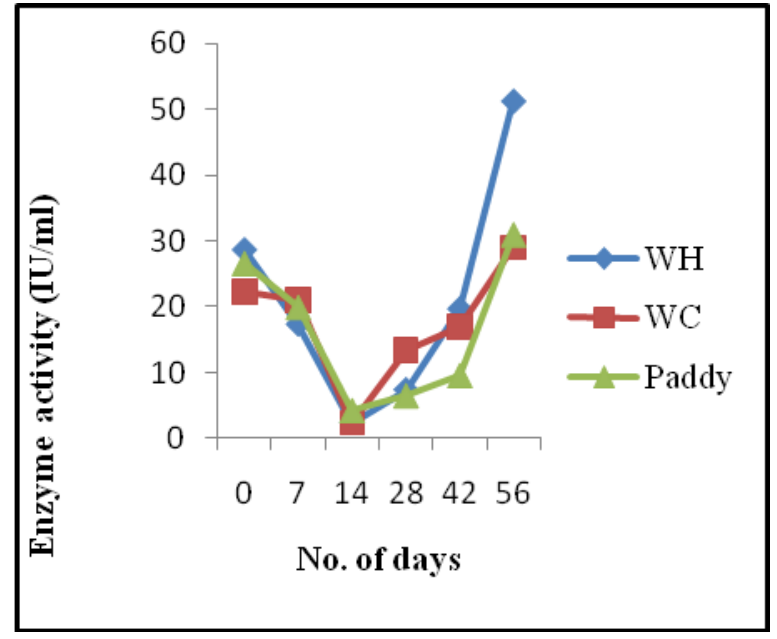

Fig.5 Comparison of pectinase activity on different substrates

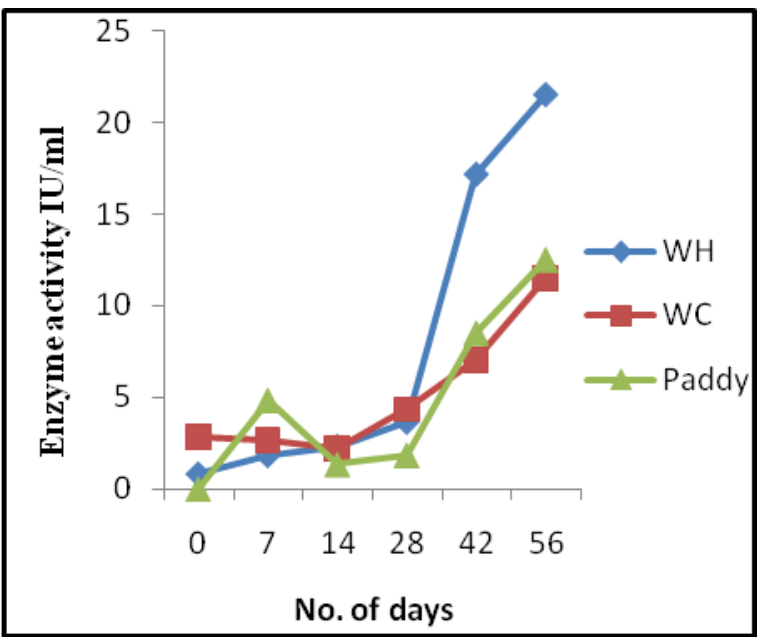

Fig.6 Comparison of reducing sugar released during fermentation

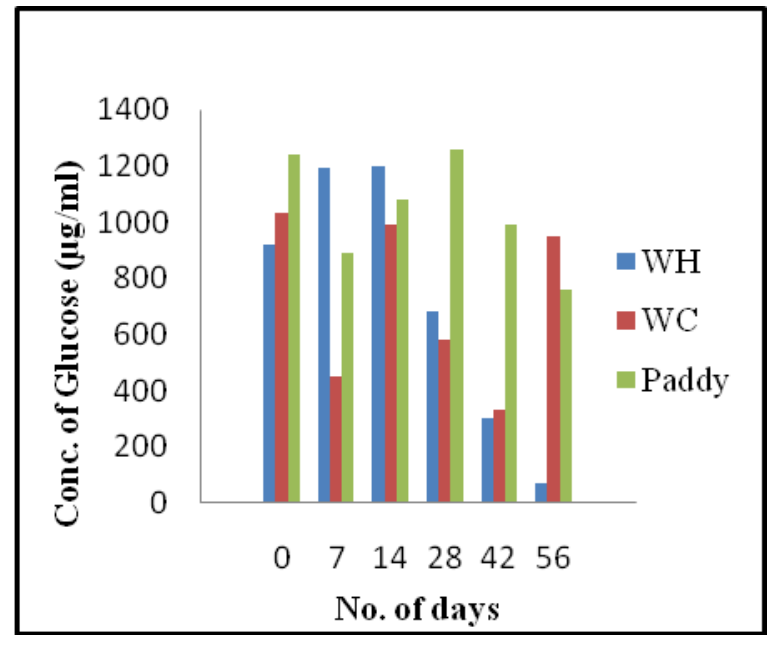

41 
Fig.7 Comparison of protein produced on different substrate

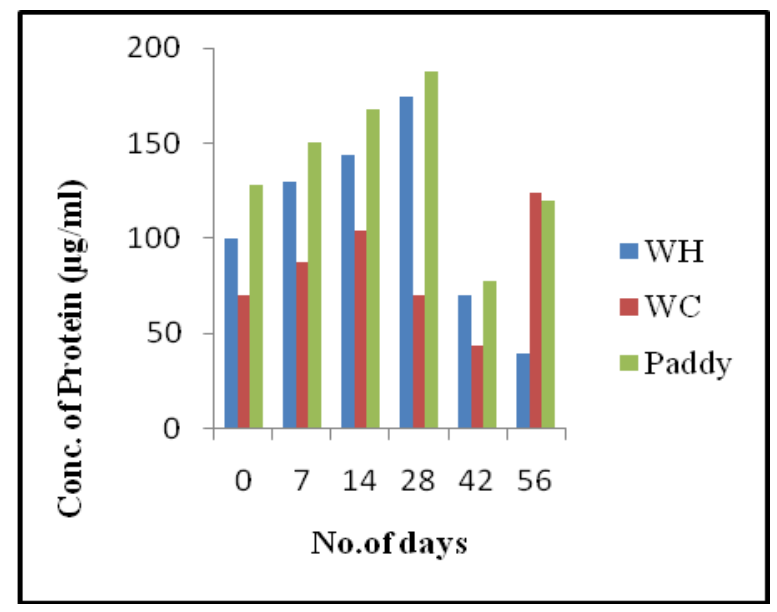

The nitrogen and phosphorus content was found to be high in water hyacinth whereas high carbon content was found in paddy (Table 4). The $\mathrm{C}$ : $\mathrm{N}$ ratio was found to be higher in paddy than other two substrates used. Hence, more yield of mushroom was obtained using paddy as substrate.

An attempt was made to utilize the water hyacinth, Eichhornia crassipes, as a substrate for oyster mushroom cultivation and a good yield was achieved. This was related to the ideal $\mathrm{C}: \mathrm{N}$ ratio and low lignin content. This technology could be very cheap and it is also a method of helping to eradicate a troublesome aquatic weed.

In the present study, the potential of lignocellulosic waste materials like water hyacinth, wood chips and paddy for the cultivation of Oyster mushroom ( $P$. sajor caju) was tested. During the present research, it was observed that $P$. sajor caju is able to grow on different lignocellulosic waste materials causing their degradation by producing a bulk of inducible lignocellulases. The nutritional composition of the mushroom Pleurotus sajor-caju grown on the hyacinth lignocelluloses compares favorably with that got when the mushroom is grown on common substrates. Cultivation of Pleurotus sajor-caju combined with waste utilization can be an economical and harmless method of waste disposal. It has nutritional benefits especially where nutritive foods are scarce and costly but lignocellulosic wastes are abundant. Enzyme production using Pleurotus spp. through SSF of lignocellulosic wastes holds a great promise in future. The protein content of mushroom grown on water hyacinth is higher as compared to other two substrates. Enzymes like cellulase, xylanase act on hemicellulosic components of wastes and convert them to simple form of sugars like oligomers which are then utilized for formation of fruiting bodies (mushroom). The production of oyster mushrooms on water hyacinth by SSF is an effective method for production of nutritional and protein rich food which also help in waste management. The findings suggest that using hyacinth substrates does not have detrimental effect in terms of the proximate composition of mushroom.

\section{Acknowledgement}

The authors are thankful to Dr. K. M. Vasudevan Pillai, Chairman and CEO, Mahatma Education Society and Dr. Daphne Pillai, Secretary, Mahatma Education Society for providing facilities for carrying out this research work at Department of Biotechnology, Pillai's College of Arts, Commerce and Science, New Panvel. We also acknowledge Principal, Hislop College, Nagpur for encouragement and technical support given for manuscript preparation.

\section{References}

Sherief, A.A., A.B. El-Tanash and A.M. Temraz. 2010. Lignocellulolytic Enzymes and Substrate Utilization during Growth and Fruiting of Pleurotus ostreatus on Some Solid Wastes, J. Environ. Sci. Technol., 3(1): 1834.

Adsul, M.G., J.E. Ghule, H. sheikh, K.B. Bastawde, D.V. Gokhale and A.J. Varma. 2005. Enzymatic hydrolysis of delignified baggase polysaccharides. Carbohydrate Polymer, 62: 6-10.

Alemawor, F., V.P. Dzogbefia, E.O.K. Oddoye and J.H. Oldham. 2009. Effect of Pleurotus ostreatus fermentation on cocoa pod husk composition: Influence of fermentation period and $\mathrm{Mn}^{+2}$ supplementation on the fermentation process. Afr. J. Biotechnol., 8: 1950-1958.

Anakalo Kihumbu, G., et al. 2008. Nutritional Composition of Pleurotus sajor-caju Grown on Water Hyacinth, Wheat Straw and Corncob Substrates Res. J. Agric. and Biol. Sci., 4(4): 321-326.

Badshah, N., Wahid, M. and Rehman, N.U. 1994. Yield and quality of mushrooms grown on different substrates. Sarhad J. Agril., 8(6): 631-635. 
Bradford, M.M. 1976. A rapid and sensitive method for the quantification of microgram quantities of protein utilizing the principle of protein dye binding. Anal. Biochem., 72: 248-254

Chang, S.T. and Miles, P.G. 1988. Pleurotus- A mushroom of broad adaptability. In: Edible Mushroom and Their Cultivation. CRC Press, Inc. Boca Raton, Florida, USA. pp 265-275.

Elisashvili, V., Penninckx, M., Kachlishvili, E., Asatiani, M., Kvesitadze, G. 2006. Use of Pleurotus dryinus for lignocellulolytic enzymes production in submerged fermentation of mandarin peels and tree leaves, Enzyme and Microbial Technol., 38: 998-1004.

Eriksson, K.E., Blanchette, R.A., Ander, P. 1990. Microbial and enzymatic degradation of wood and wood components. [In:] Springer Series in Wood Science. Springer-Verlag Berlin.

Fiske, C.H., Subbarow, Y.J. 1925. The colorimetric determination of Phosphorus, Biol. Chem., 66: 375400.

Garzillo, A.M.V., S. Di Paolo, M. Ruzzi and V. Buonocore. 1994. Hydrolytic properties of extracellular cellulases from Pleurotus ostreatus. Appl. Environ. Microbiol., 42: 476-481.

Heleno, S.A., Barros, L., Sousa, M.J., Martins, A., Ferreira, I.C.F.R. 2010. Tocopherols Composition of Portuguese wild mushrooms with antioxidant capacity. Food Chem., 119: 1443-1450.

Iqbal, M. and A. Shah. 1989. Effect of CaCO on substrate of Pleurotus sajor-caju. Sarhad J. Agric., 5: 359-361.

Jones, D.B., Munsey, V.E., Walker, L.E. 1942. Report of Committee on Protein Factors, J. Assoc. Agricultural Chem., 25: 118-120.

Kadari, M. 1999. Changes in intracellular and extracellular enzyme activities of Lentinus subnudus during sporophore development. Biosci. Res. Commun., 11: 127-130.

Kirk, T.K., Farrell, R.L. 1987. Enzymatic combustion: the microbial degradation of lignin. Annu. Rev. Microbiol., 41: 465-505.

Mattila, P., Könkö, K., Eurola, M., Pihlava, J.M., Astola, J., Vahteristo, Hietaniemi, V., Kumpulainen, J., Valtonen, M., Piironen, V. 2001. Contents of vitamins, mineral elements, and some phenolic compounds in cultivated mushrooms. J. Agric. Food Chem., 49: 2343-2348.
Miller, G.L. 1959. Use of dinitrosalicylic acid as reagent for determination of reducing sugars. Anal. Chem., 31: 426-8.

Omoanghe, I.S., Mikiashvili, N.A. 2009. Lignocellulolytic enzyme activity, substrate utilization, and mushroom yield by Pleurotus ostreatus cultivated on substrate containing anaerobic digester solids. J. Ind. Microbiol. Biotechnol., 36: 1353-1362.

Quinnghe, C., Y. Xiaoyu, N. Tiangui, J. Cheng and M. Qiugang. 2004. The screening of culture condition and properties of xylanase by white-rot fungus Pleurotus ostreatus. Process Biochem., 39: 1561-1566.

Royse, D.J. 2005. Foreward to Fifth international conference on mushroom biology and mushroom products. Acta Edulis Fungi, (suppl.). 12: 1-2.

Ryu, D.D.Y., and Mandela, M. 1980. Cellulases: Biosynthesis and applications. Enzyme Microbial Technol., 2: 91-102.

Sarker, N.C., M.M. Hossain, N. Sultana, I.H. Mian, A.J.M. Sirajul Karim and S.M. Ruhul Amin. 2007. Impact of Different Substrates on Nutrient Content of Pleurotus ostreatus (Jacquin ex Fr.) Kummer. Bangladesh $J$. Mushroom, 1(2): 51-56.

Stajic, M., Persky, L., Friesem, D., Hadar, Y., Wasser, S. P., Nevo, E., Vukojevic, J. 2006. Effect of different carbon and nitrogen sources on laccase and peroxidases production by selected Pleurotus sp., Enzyme and Microbial Technol., 38: 65-73.

Sun, R., J. Lawther and W. Banks. 1996. Fractional and structural characterization of wheat straw hemicelluloses. Carbohydrate Polymer, 29: 325-331.

Techapun, C., Poosaran, N., Watanabe, M., Sasaki, K. 2003. Thermostable and alkaline-tolerant microbial cellulase-free xylanases produced from agricultural wastes and the properties required for use in pulp bleaching bioprocess: a review, Process Biochem., 38: 1327-1340.

Walkley, A. and I.A. Black. 1934. An Examination of Degtjareff Method for Determining Soil Organic Matter and a Proposed Modification of the Chromic Acid Titration Method. Soil Sci., 37: 29-37.

Zaman, M.A. 2004. Effect of growth regulators and organic and inorganic amendments on growth and yield of oyster mushroom (Pleurotus ostreatus). M. S. Thesis, Bangabandhu Sheikh Mujibur Rahman Agricultural University, Gazipur.

\section{How to cite this article:}

Rashmi Padhye and Sneha Atawane. 2017. Cultivation of Oyster Mushroom and Recovery of Value Added by- products from Biodegradable Lignocellulosic Waste Materials by Solid State Fermentation. Int.J.Curr.Res.Aca.Rev. 5(2), 34-43. doi: http://dx.doi.org/10.20546/ijcrar.2017.502.005 